Du Jianlu

\title{
A Document from Tangut State Regarding the Lease of a Bakery
}

DOI $10.17816 /$ wmo35113

Abstact: The paper is focused on the study of Document Дx-18993 "Agreement on a Bakery Lease to Li Chungou and others, drawn as a result of a contest of tenders conducted in the 1st month of the 12th year of the Guangding reign era" kept in the Institute of Oriental manuscripts of the RAS. The writer of the paper proves that the document originates from Khara-Khoto and gives the comments on its content.

Key words: Khara-Khoto, Tangut state, rent documents, bakery lease

Published in volume 17 of the facsimile edition of Documents from Dunhuang kept in Russia (Ecang Dunhuang Wenxian), was a unique fragment titled "Agreement on a Bakery Lease to Li Chungou and others, drawn as a result of a contest of tenders conducted in the 1st month of the 12th year of the Guangding reign era" (Guangding shi er nian deng Li Chungou pumai bing fangqi光定十二年李春狗等撲賣餅房契)». ${ }^{1}$ Although the document is kept in the Dunhuang Fund of the Institute of Oriental Manuscripts of the RAS catalogued as Дx-18993, it clearly does not originates from Dunhuang, coming almost definitely from Khara-Khoto. The Guangding era was proclaimed by the Xi Xia Emperor Li Zunxu (Shenzong) and the 12th year of his reign corresponds to 1222 , consequently the lease document was written five years prior to the fall of the Tangut state. In the opinion of the Chinese scholars Nie Xiaohong and Chen Guocan, the above agreement was concluded in Xi Xia, which is corroborated by the following facts. First, up to now no documents written in the final years of Western Xia have ever been found among the manuscripts discovered in Dunhuang. Second, the document made use of the collocations "the person who has tabled the lease" (li wenzi ren 立文字人) and "those who have jointly tabled the lease" (tong li wenzi ren

(C) Du Jianlu, Ningxia University, China, 2020

${ }^{1}$ Ecang Dunhuang Wenxian, vol. 17, p. 310. 
同文字人); formulas like those are only found in documentation from Western Xia and the Yuan dynasty and never in Dunhuang. Third, the formulaic phrase "need not be further discussed" ( $b u$ ci 不詞) was favoured exclusively in documents from Khara-Khoto. Fourth, no vocabulary item like "bakery" or "flatbread shop" (shao bing fang 燒餅房) has ever been discovered in documents from Dunhuang either. ${ }^{2}$

Apart from this, we believe there is another important point in support of the Tangut origins of the lease paper: the present piece is not the only document from Khara-Khoto included in the publication called Documents from Dunhuang kept in Russia. In the Дx index category, quite a few Khara-Khoto documents have figured: e.g. Дx-18992 "Document of the Chief Administration of the Yijinai District" (Yijinai lu zong guanfu wenshu 亦集乃 路總 管府文書), Дx-18996 "Marriage Contract of Buyanchaomu from the Yijinai District" (Yijinai lu Buyanchaomu tonghunshu 亦集乃路不顏抄木合 同婚書), Дx-19022 "Receipt certifying payment for a purchased quantity of sulphur in year 23 of the Zhizheng reign era of the Yuan dynasty" (Yuan Zhizheng er shi san nian zhifu mai liuhuang qian shouju 元至正廿三年支付 賣硫磺錢收據), Дx-19043 “Document dated year 24 of the Qianyou reign era in the state of Xi Xia" (Xi Xia Qianyou er shi si nian weishu 西夏乾祐廿 四年文書), Дx-19070 “Document on purchases of horse fodder in year 1 of the Zhiyuan reign era of the Yuan dynasty" (Yuan Zhiyuan nian xian hedi maliao wenshu 元至元年閒和櫂馬料文書), Дx-19072 “Report dated year 3 of the Zhizheng reign era of the Yuan dynasty on the provision of nourishment to the aged and orphaned" (Yuan Zhizheng san nian qing zhi gu lao kouliang chengzhuang 元至正三年請支孤老口粮呈狀), Дx-19073 “Document dated year 2 of the Taiding reign era of the Yuan dynasty" (Yuan Taiding er nian wenshu 元泰定二年文書), Дx-19087 “Several documents in Xi Xia writing” (Xi Xia wen ji shu wenshu 西夏文記数文書) and so on.

Professors Nie Xiaohong and Chen Guocan mainly addressed the origins of "Agreement on a Bakery Lease to Li Chungou" hardly touching upon its content. This article will attempt to right the shortcoming.

Among the lease documents from the Sui, Tang, Song, Liao, Xia, Jin and Yuan dynasties, most related to the rent of land, while agreements on housing space were scarce and extremely fragmentary. ${ }^{3}$ The document we are publishing is the most detailed of those that have come down to us.

The following is the reproduced original text and our comments on it.

\footnotetext{
${ }^{2}$ NiE Xiaohong, Chen Guocan 2009.

${ }^{3}$ ZHANG Zhuanxi 1995, 274, 303-304.
} 
光定十二年正月廿一日立文字人李春狗、劉

番家等, 今於王元受處撲到面北燒餅房舍一位, 裏九五行動用等全, 下項內 炉鏊一富, 重四十斤, 無底。大小錚二口, 重廿五斤。鐡匙一 張, 餬餅划一張, 大小檻二个, 大小岸三面, 升房斗二面, 大小口袋二 个, 裏九 小麥本染石伍斗。每月行價賃雜 壹石伍斗, 恒月係送納。每 月不送納, 每一石倍 罰一石與元受用。撲限至伍拾日, 如限滿日, 其五 行動用, 小麥七石五斗, 迴与王元受。如限日不迴還之時, 其五行動用、 小麥本每一石倍罰 一石; 五行動用每一件倍罰一件与元受用。如本 人 不迴与不辨之時, 一面契內有名人當管填還數足, 不詞。只此文契為憑。

立文字人李春狗 [押]

同立文字人李來狗

同立文字人郝老生[押] 立文字人劉番家[押] 同立文字人王號義[押] 同 立文字人李喜狗 知見人王三宝 知見人郝黑見

$P u$ or pumai (撲賣) is one of the ways of business contracting in medieval China, where it came into being during the second half of the Tang dynasty's reign and became widespread under the North Song. ${ }^{4}$ It was then that it gained currency not only in the economically developed south-east, but emerged on the faraway north-west outskirts of the empire. In the sixth month of fifth year of the Dazhong-xiangfu period (1012) of Emperor Zhenzong's reign, "Cao Wei, the military chief of the Jinyuan Province, remarked that the inhabitants of frontier fortresses had just been permitted to buy shops on competitive basis and to trade in wine right on the border itself. He feared lest bad guys should be hiding there and asked for a ban on the practice. The emperor agreed with him". ${ }^{5}$ In the Tiansheng years (1023-1031) the pumai license validity was extended from one to three years. ${ }^{6}$ The following procedure for pumai leasing had formed: half a year before announcing the contest, the authorities "posted an advertisement at the liveliest spot in the locality and for two months tried to lure prospective buyers". ${ }^{7}$ Those who were interested were supposed to apply in writing and the authorities kept their tenders secret. As the deadline arrived, the bids were publicly disclosed and the contract was won by the highest bidder. If two top candidates offered the same amount, the

\footnotetext{
${ }^{4}$ Li Huarui 1995, 191.

${ }^{5}$ Song huiyao jigao, ch. 20, 5.

${ }^{6}$ Song huiyao jigao, цз. 20, 7.

${ }^{7}$ Xu Zizhi tongjian changbian, ch. 271 (Xining san nian shi yi yue jia $w u$ 熙宁三年十一月甲午).
} 
contest was won by the bidder that had applied earlier than the other one. ${ }^{8}$ If later anybody offered a higher price than the former participants in the competition, the contest winner was offered to outbid the new offer. If he did not want to, the contract was given to the last bidder ${ }^{9}$. The context results were properly promulgated. ${ }^{10}$

In sum, the contract license was given to anyone who had offered the highest price, but if afterwards the winner did not run the business effectively or even went bankrupt, the person was forced to sell the possessions deposited as pledge. If there was nobody desirous of buying those, neighbors' were coerced to do so. If the neighbors' could not afford buying those possessions, the authorities searched for more distant buyers. If after the sale of personal effects the former contractor was still in debt to the authorities, the contract warrantor was ordered to pay the amount outstanding. ${ }^{11}$

Besides wine shops, the pumai came to be applied to other spheres of monopoly trade. ${ }^{12}$ During the Song dynasty, the pumai activities were adopted by the government. The document being published herewith proves, however, that the practice existed also as a method accessible to ordinary people. Li Chungou availed himself of the right to rent the bakery because he had paid the highest price. This fact evidences considerable changes seen in the public and economic life of Xi Xia and in the whole of China in those days.

Shaobing (燒餅) and hubing (餬餅) were two favourite Tangut types of food. According to "A Timely Pearl in the Hand" (Fan han heshi zhang zhong $z h u$ (番漢合時掌中珠) Dictionary, the Tangut dough-based cuisine included youbing (油餅), hubing (胡餅), zhengbing (蒸餅), ganbing (乾餅), shaobing (燒餅), huabing (花餅), youqiu (油球), jiaozi (餃子) and mantou (饅頭). ${ }^{13}$ The word shaobing is spelt with two symbols of the Tangut writing system, the first of which is pronounced as bei meaning "baked" and the other as $e$, meaning "flatbread". The shaobing seems to have been like a flatbread baked in the luao (爐鏊) oven. The word hubing (餬飭) also spells with two symbols, the first pronounced with two symbols, the first of which is a homophone of the Tangut word for "oven"; the second symbol is pronounced as yize, as is oven; it includes part of the character from the word denoting

${ }^{8}$ Xu Zizhi tongjian changbian, ch. 220 (Xining si nian er yue ding si 熙宁四年二月丁巳).

${ }^{9}$ Xu Zizhi tongjian changbian, ch. 217 (Xining san nian shi yi yue jia $w u$ 熙宁三年十一月甲午).

${ }^{10}$ Xu Zizhi tongjian changbian, ch. 218 (Xining san nian shi yi yue ding yichou 熙宁三年十月乙丑).

${ }^{11}$ LÜ Tao, ch. 2, 1098-1020.

${ }^{12}$ Cf. OUYANG Xiu, 914.

${ }^{13}$ Ecang Heishuicheng wenxian, vol. 10, 1-19. 
oven; the second symbol is pronounced as $e$ and means "flatbread". In ancient China a baked flatbread sprinkled with sesame seeds was called hubing or mabing. The Tangut hubing (胡餅) should have been essentially the same flatbread, but baked in zheng (鋝)rather than in ao (鏊) ovens.

Together with the premises of the bakery, the properties on lease included also ao and zheng ovens, a large and a small iron ladle, a trowel for hubing, a large and a small kan (檻) closet, three large and small kitchen boards, two measures of shengfangdou (升房斗), a large and a small sack, seven dan (石) and five dou (斗) of wheat.

There existed two types of ao - one looked like a flat-bottomed pot and was called bing-ao (餅鏊) or bingguo (餅鍋). In the third year of the Dazhong-xiangfu period of the Song dynasty (1010) Zhao Deming, ruler of Xiping, "built a great many palaces on the slopes of Aojishan Mount". ${ }^{14}$ The name of the mountain indicated that its top was concave like a pot bottom. The luao flatbread oven mentioned in the document looked like a pail without a bottom. Firewood was burnt in its lower part, while dough for flatbread was pasted and baked on the inner sides of the walls in the upper part of the oven.

The zheng character (鋝) denoted an ancient musical instrument resembling a copper gong. Here it represents a kitchen utensil - a flat-bottomed pot in which hubing is baked.

The iron ladle was evidently designed for drawing water or flour with. The hubing trowel was known as hubing chan (餬餅鏟); it was used in the baking of hubing. Kan (檻) or gui (柜) denoted wooden vessels to hold water or something else. The "Mixed Symbols" dictionary ( $\mathrm{Zi} z a$ 字雜) includes “wooden kan” (木檻) ${ }^{15}$. The Nong sang kuai xun (農桑快訙) essay states: "On the left bank of the Yangtze river grass grows; it is mown and soaked in a big kan. When the grass gets sour and yellows, it is admixed to bran. This sort of extra nourishment mixture is good for fattening livestock". ${ }^{16}$

No mention was made in the document of a tub for water or a kneading trough, therefore what was called a large and a small kan probably referred to containers for water and dough. An (案) was a kitchen board to knead and roll dough on.

Koudai (口袋) were woolen or cotton sacks for storing flour, rice and other grain. Sheng and dou were measuring units of volume, one dou containing ten

\footnotetext{
${ }^{14}$ Song shi, ch. 485 (Xia guo zhuan shang 夏國傳上).

${ }^{15}$ Cf. SHI Jinbo 1989.

${ }^{16}$ Xu Guangqi, ch. 41 (Nong sang kuai xun 農桑快訙).
} 
sheng. Inside the measuring tool leased, a fang container was installed; therefore the "tool" was referred to in the text as shengfangdou.

According to the text of the document, the lessee renting the bakery together with all the requisite utensils plus 7 dan 5 dou of wheat had to return monthly 1 dan 5 dou of assorted grain. ${ }^{17}$ The monthly interest rate amounted to 20 per cent.

In the Tangut state, grain would generally be borrowed in March-April, when the old harvest stocks were almost exhausted and the new crops were standing; debts were returned in July-August from new harvest. Interest rates ranged from 30 to 100 per cent, the latter known as "double interest" (beicheng zhi xi 倍稱之息). A number of similar examples are found in documents from Khara-Khoto. A curious case is on record when a quantity of grain was borrowed in the fourth month of year six in the Tianqing era and returned on 1 August. For each dou borrowed the amount returned was 1 dou and 7 sheng, i.e. return per $1 \mathrm{dou}$ was $1 \mathrm{dou}$ and 7 sheng. The interest over four months amounted to 70 per cent -17.5 per cent a month. Another example. In May of year 12 in the Tianqing era some wheat was borrowed. It was returned on 1 August, with 4 sheng added to each dou borrowed. It came to a 40 per cent return over three months, 13.3 per cent interest repaid monthly. In January of year 12 of the Guangding period, Li Chungou and others borrowed a quantity of wheat at an interest rate of 20 per cent. The rate was high, for which there were two reasons: first, the owner lent wheat to Li Chungou, whereas the requital was in "assorted grains". Wheat and "assorted grains" differed in price. Secondly, the lease included not only repayment for the wheat, but also for the premises and utensils. Taking all this into account, we can observe that between the Tianqing and the Guangding periods KharaKhoto saw relative stability in lease interest rates and commodity prices.

The document was signed by two persons, evidently by the married couple of Li Chungou 李春狗 and Liu Fanjia 劉番家. It was very rare for Western Xia documentation to have a paper signed simultaneously by the husband and wife. In ancient China, married women were not officially called by their feminine names. They were usually referred to by their husband's names e.g., “Liu's wife" (Liu jia de 劉家的), Li's wife (Li jia de 李家的) and so on. Evidently, Liu Fanjia is a feminine name. Fan reads $m i$ in Tangut and it was the Tanguts' national self-identity name. ${ }^{18}$ Perhaps the Tangut custom did not

\footnotetext{
17 “Assorted” or “ancillary” ( $z a$ 雜) cereals — like barley, buckwheat, etc. Their market prices were much lower than those of wheat.

${ }^{18}$ Cf. Shi Jinbo, Bai Bin, Huang Zhenhua 1983.
} 
require a woman to bear her husband's name. This supposition, however, needs further study.

The name Li Chungou translates as "springtime dog". In the names of the document cosignatories, Li Laigou and Li Xigou, evidently his kinsmen, the character "dog" is also present. Names like this were not uncommon for Tanguts, especially those living in out-of-the way places. Their babies were given lowly names like gou ("dog"), zhu ("pig") in the belief that it would be easier to raise them that way. For example, in the document dated year 12 of the Qianding Western Xia period, asking for a lease on the pledge of a quantity of millet, the applicant's name is He Gougou 何狗狗 and the name of the witness is Lishang Shigou 李膻使狗. In a document from the Qianyou years we come across such names as Sun Zhugou 孙猪狗, Bai Bangou 白伴 狗, Li Zhuer 李猪儿, as well as the name Zhao Zhugou 趙猪狗 in the document registered as inv. № $7465 \mathrm{v}$, and so on.

\section{References}

Ecang Heishuicheng wenxian 俄藏黑水城文獻 [Manuscripts from Kharo-Khoto kept in Russia]. Shanghai: Shanghai guji chubanshe 上海: 上海古籍出版社. Vol. 10, 1999, vol. 17, 2001.

Li Huarui 李華瑞 1995: Song dai jiu de shengchang yu zheng que [On Wine Production and Monopoly in the Song Epoch] 宋代酒的生産與徵榷. Baoding: Hebei daxue chubanshe 保定 : 河北大學出版社, 1995.

[Song] LÜ Tao [宋]吕陶. Jing de ji [Collection of Purest Virtue] 凈德集. Sibu ying yin ben 四库影印本. Shanghai, 1934.

NIE Xiaohong 也小红, CHEN Guocan 陳國燦. 2009: Heishuicheng suo chu Xixia Zhiyuan de ji jian qiyue yanjiu [About Several Contracts of the Xi Xia Zhiyuan Period discovered in Khara-Khoto] 黑水城所出西夏至元的幾件契約研究. Report Delivered at the Silk Way International Academic Seminar in Yinchuan on 21-22 August 2009 [8 月 21-22 日2009 年，銀川，“絲綢之路“國際學術研討會論文].

[Song] OuYANG Xiu [宋]歐陽修. Ouyang Xiu quan ji [Complete Works by Ouyang Xiu] 歐陽 修全集. Beijing: Zhongguo shudian 北京：中國書店, 1986.

SHI Jinbo 史金波 1989: Xi Xia Han wen ben “Za zi” chu tao [A Preliminary Study of the Chinese Text Titled "Mixed Symbols from Kharo-Khoto"] 西夏漢文本〈雜字〉初探 // Zhongguo minzu shi yanjiu [Studies of the History of China's Peoples] 中國民族史研究. Is. 2. Beijing: Zhongyang minzu daxue chubanshe 北京: 中央民族大学出版社, 1989, $167-185$.

SHI Jinbo 史金波、BAI Bin 白滨、HuANG Zhenhua 黄振華 1983: Wen hai yanjiu [Analysis of “The Sea of Letters” Dictionary] “文海研究. Beijing: Zhongguo shehui kexue chubanshe 北京: 中國社會科學出版社 1983 .

Song shi 宋史 [History of the Song Dynasty]. Ed. by Tuotuo 脱脱. Beijing: Zhonghua shuju 北京：中華書局, 1997. 
[Ming] Xu Guangqi [明] 徐光啟. Nong zheng quan shu [Complete Survey of Agriculture] 農政全書. Shanghai: Shanghai guji chubanshe 上海：上海古籍出版社, 1979.

[Qing] XU Song [清] 徐松. Song huiyao jigao [Draft Materials for "Basic Information on the Song Epoch”] 宋會要輯稿. Beijing: Zhonghua shuju 北京：中華書局, 1957.

Xu Zizhi tongjian changbian 續資治通鑑長編 [Materials in Continuation of “Comprehensive Mirror to Aid in Government”]. Ed. by Li Tao. 李壽. Beijing: Zhunghua shuju 北京 : 中華 書局, 2004.

ZHANG Zhunxi 張傳需 1995: Zhongguo lidai qiyue huibian kaoshi [Ancient Chinese Contracts with Analysis and Comments] 中國歴代契約彙編考釋. Ed. by Zhang Zhuanxi. Beijing: Beijing daxue chubanshe 北京: 北京大學出版社, 1995. 